\title{
PROFIL EFEKTIVITAS PLATFORM BLENDED LEARNING BERBASIS TKP- KELASE PADA PEMBELAJARAN MATEMATIKA
}

\author{
I Putu Wisna Ariawan $\left(\mathbb{1}^{1)}\right.$, Dewa Gede Hendra Divayana $\left(^{2)}\right.$, dan P Wayan Arta Suyasa $\left(^{3)}\right.$ \\ ${ }^{1}$ Pendidikan Matematika, Universitas Pendidikan Ganesha \\ ${ }^{2,3}$ Pendidikan Teknik Informatika, Universitas Pendidikan Ganesha \\ ${ }_{1,2,3} \mathrm{Jl}$. Udayana No. 11 Singaraja, Bali, 81116 \\ E-mail : wisna.ariawan@undiksha.ac.id ${ }^{1)}$, hendra.divayana@undiksha.ac.id ${ }^{2)}$, arta.suyasa@undiksha.ac.id ${ }^{3)}$
}

\begin{abstract}
ABSTRAK
Penelitian ini bertujuan untuk mengetahui profil efektivitas platform blended learning berbasis TKP (Tri Kaya Parisudha)Kelase pada pembelajaran Matematika. Penelitian ini adalah jenis penelitian deskriptif kualitatif. Pada tahap pelaksanaan kegiatan, hal-hal yang dilakukan meliputi: pemilihan subjek dilakukan secara acak dengan mempertimbangkan tingkat kemampuan Matematika yang diukur dengan memperhatikan skor hasil tes Matematika; melaksanakan pembelajaran menggunakan platform blended learning berbasis TKP-Kelase dan wawancara pada subjek; dan melakukan triangulasi data. Hasil penelitian ini menemukan bahwa profil efektivitas platform blended learning berbasis TKP-Kelase pada pembelajaran Matematika memenuhi standarisasi pada 3 kategori yaitu Kriteria Pendidikan (Educational Criteria), Tampilan Program (Cosmetic), dan Kualitas Teknis (Technique Quality). Adapun profil efektifitas nya adalah: Topik-topik materi untuk setiap jenjang pendidikan SMA/SMK yang dimasukkan dalam blended learning sudah sesuai dengan kurikulum 2013 (EC1); Materi pembelajaran Matematika sudah tersusun dari tingkat kesulitan terendah sampai dengan tertinggi (EC2); Konsep Manacika, Wacika, dan Kayika sudah mampu menginternalisasi dalam proses pembelajaran melalui fitur-fitur yang disediakan dalam blended learning yang dibuat dengan platform kelase (EC3, EC4, dan EC5); Tampilan blended learning menarik (C1); Blended learning mudah diakses $(\mathrm{C} 2)$; Penyimpanan data pada blended learning stabil (C3); Keamanan data terjaga (C4); Dapat digunakan oleh multi user dalam waktu bersamaan (C5); Fitur-fitur blended learning yang dibuat menggunakan platform Kelase mudah dioperasikan (TQ1); Blended learning menyediakan fasilitas yang memudahkan untuk mengunggah tugas (TQ2); Blended learning menyediakan fasilitas forum diskusi antara siswa dengan guru, siswa dengan siswa (TQ3).
\end{abstract}

Kata Kunci: Efektivitas, Platform, Blended learning, TKP-Kelase, Matematika

\section{PENDAHULUAN}

Adanya pandemi Covid-19 mempengaruhi metode pengajaran dan praktik kelas para guru secara tiba-tiba. Pembelajaran di masa pandemi Covid-19 harus mengarah ke opsi online yang lebih efektif dalam jangka panjang (Dolighan \& Owen, 2021). Hal tersebut tidak luput dari dukungan persiapan dalam hal infrastruktur, sikap dan keterampilan untuk pendekatan, serta aplikasi pendidikan online yang inovatif. Berkaitan dengan keberhasilan proses pembelajaran Matematika pada masa pandemi Covid-19, walaupun dilaksanakan secara online haruslah tetap memperhatikan tahap perkembangan berpikir anak dari Piaget, sehingga proses pembentukan konsep oleh anak dapat dikatakan tuntas (Babakr, Mohamedamin, \& Kakamad, 2019).

Pada era revolusi industri 4.0 seperti saat ini, sudah mulai bermunculan hybrid learning dengan menerapkan model blended learning yang ditunjang dengan platform dan aplikasi gratis dari internet sehingga dapat digunakan sebagai media penunjang pembelajaran Matematika agar dapat meningkatkan kemampuan kognitif siswa. Model blended learning tersebut menyediakan konten materi dan soal-soal dengan tingkat kesulitan berjenjang mulai level rendah sampai level tersulit untuk melatih kemampuan kognitif siswa dalam memahami pelajaran Matematika secara mandiri di luar kelas maupun secara bersama-sama saat bertatap muka dengan guru di kelas. Ketuntasan ini terindikasi dalam tiga ranah yang dikemukakan Bloom. Dimana tiga ranah ini menjadi pusat perhatian dalam mempelajari konsep untuk melihat ketuntasan proses yang terjadi. Ketiga ranah tersebut meliputi ranah kognitif (pengetahuan), ranah afektif (sikap), dan ranah psikomotorik (keterampilan) (Arifin, Febriani, \& Anasruddin, 2021).

Proses pembelajaran learning yang diharapkan dapat terjadi di era revolusi industri 4.0 ini tidak hanya sekadar untuk menghasilkan siswa dengan kemampuan tinggi pada ranah kognitif saja, melainkan juga kemampuan siswa pada ranah afektif dan psikomotorik. Untuk menjawab harapan tersebut, maka perlu dikembangkan suatu model blended learning menggunakan platform aplikasi gratis dari internet dengan konten materi dan proses pembelajaran nya mengadopsi kearifan lokal sehingga dapat mewujudkan pembelajaran Matematika yang berkualitas mengacu pada ranah kognitif, afektif, dan psikomotorik. 
Mengingat sulitnya mencapai semua hal tersebut melalui peralatan teknis dan dengan adanya hambatan spasial, maka konsep blended learning dapat dijadikan suatu solusi untuk menghindari hal-hal negatif akibat pemanfaatan teknologi. Konsep blended learning dapat mengarahkan pembelajaran untuk meningkatkan efektivitas nya dan terintegrasi dengan pembelajaran tradisional untuk meningkatkan efisiensi serta meningkatkan luaran nya (Green \& Whitburn, 2016). Blended learning tidak terbatas pada penggunaan teknologi, tetapi lebih merupakan desain ulang semua pilar proses pendidikan, dan penataan peran masingmasing peserta didik dan guru, bahkan posisi pendidikan secara keseluruhan (Busto, Dumbser, \& Gaburro, 2021). Blended learning didasarkan pada upaya untuk memaksimalkan keuntungan dari pembelajaran tradisional dan e-learning untuk mencoba menghindari kerugian dari pelaksanaan keduanya jika dilakukan secara terpisah dan sendiri-sendiri (EL-Ariss, Zaneldin, \& Ahmed, 2021).

Beberapa hasil penelitian terkait blended learning yang pernah dilakukan oleh peneliti terdahulu menghasilkan beberapa temuan dan keterbatasan yang mendasari munculnya penelitian ini sebagai jawabannya. Penelitian Muhtia, Suparno, \& Sumardi (2018) menunjukkan penggunaan schoology sebagai platform penunjang penyelenggaraan blended learning. Keterbatasan penelitian Muhtia, Suparno, \& Sumardi adalah tidak ditunjukkan wadah dalam platform schoology yang dapat digunakan untuk mengemas konten dan bentuk test pada blended learning secara menyeluruh dari ranah kognitif, afektif dan psikomotorik. Pemanfaatan moodle sebagai platform blended learning. Keterbatasan penelitian Sulisworo, Agustin, \& Sudarmiyati adalah platform moodle yang digunakan dalam blended learning belum memfasilitasi konten materi dan bentuk test yang mengacu ranah kognitif, afektif, dan psikomotorik secara menyeluruh (Sulisworo, Agustin, \& Sudarmiyati, 2016). Penggunaan platform quipper school untuk menunjang blended learning. Keterbatasan penelitian Wijanayu, Hardyanto, \& Isnaeni adalah belum menunjukkan konten materi dan bentuk tes yang mengacu ranah kognitif, afektif dan psikomotorik, namun hanya fokus pada ranah kognitif saja (Wijanayu, Hardyanto, \& Isnaeni, 2018). Penggunaan platform Edmodo untuk menyelenggarakan blended learning. Keterbatasan penelitian Helsa \& Kenedi adalah tidak menunjukkan konten materi dan bentuk test yang mengacu pada domain kognitif, afektif dan psikomotorik untuk menghasilkan hasil belajar yang efektif (Helsa \& Kenedi, 2019).

Menjawab permasalahan-permasalah tersebut diatas (Ariawan, Divayana, \& Suyasa, 2020) telah berhasil melakukan penelitian yang menemukan suatu inovasi baru melalui modifikasi platform Kelase yang di integrasi dengan konsep Tri Kaya Parisudha. Hal yang dimaksudkan di sini adalah keberhasilan dalam mewujudkan suatu platform blended learning yang berisi konten materi untuk mengukur tiga ranah ketuntasan hasil belajar yang berlandaskan konsep Tri Kaya Parisudha. Manacika (berpikir yang baik) dalam konsep Tri Kaya Parisudha digunakan sebagai landasan mengukur kemampuan kognitif siswa. Wacika (berkata yang sopan) dalam konsep Tri Kaya Parisudha digunakan sebagai landasan mengukur kemampuan afektif siswa. Kayika (bersikap yang baik) dalam konsep Tri Kaya Parisudha digunakan sebagai landasan mengukur kemampuan psikomotorik. Selain telah dilakukan uji coba lapangan, Ariawan dkk juga telah melakukan penelitian tentang tingkat efektifitas platform blended learning berbasis TKP-Kelase pada pembelajaran Matematika siswa SMA/SMK. Namun dalam hal ini belum dikemukakan profil efektifitas nya platform blended learning tersebut, sehingga pada penelitian ini membahas profil efektivitas platform blended learning berbasis TKP-Kelase pada pembelajaran Matematika siswa SMA/SMK, studi kasus di Bali.

\section{RUANG LINGKUP}

Penelitian ini dilakukan terbatas pada siswa SMA/SMK di Bali yang mengikuti pembelajaran Matematika menggunakan platform blended learning berbasis TKP-Kelase. Variabel-variabel yang di teliti terbatas pada profil efektivitas platform blended learning berbasis TKP-Kelase dalam tiga kategori yaitu Kriteria Pendidikan (Educational Criteria), Tampilan Program (Cosmetic), dan Kualitas Teknis (Technique Quality) (Sugiharni, 2018).

\section{BAHAN DAN METODE}

Penelitian ini adalah jenis penelitian deskriptif kualitatif. Pada tahap pelaksanaan kegiatan yang dilakukan adalah:

1. Pemilihan subjek dilakukan secara acak dengan mempertimbangkan tingkat kemampuan Matematika yang diukur dengan memperhatikan skor hasil tes Matematika. Peneliti memilih siswa yang berkemampuan setara yakni pada kategori sedang berdasarkan skor hasil tes yang diperoleh siswa sesuai dengan hasil pengelompokan.

2. Melaksanakan pembelajaran menggunakan platform blended learning berbasis TKP-Kelase dan wawancara pada subjek dengan tujuan untuk mengetahui profil efektivitas penggunaan platform blended learning berbasis TKP-Kelase pada pembelajaran Matematika siswa SMA/SMK

3. Melakukan triangulasi data. Pada tahap analisis data, kegiatan yang dilakukan adalah mengikuti langkahlangkah analisis data yang terdiri dari kategorisasi data, reduksi data, penyajian data, penafsiran data, dan kesimpulan. Penelitian tentang profil efektivitas penggunaan platform blended learning berbasis TKP-Kelase pada pembelajaran Matematika siswa SMA/SMK ini studi kasusnya adalah di Bali. Sumber data dari penelitian kualitatif ini diperoleh 
dari siswa, guru dan para pakar. Data kualitatif yang diperoleh berupa hasil study pustaka, wawancara dan hasil analisis kurikulum.

\section{PEMBAHASAN}

Pada data yang terkumpul dilakukan pelabelan untuk memudahkan penyajian data secara lengkap. Adapun pelabelan data diberikan simbol sebagai berikut.

\begin{tabular}{|llcccc|}
\hline Simbol & $:$ & P/S & F/M & T & 1 \\
Digit & $:$ & 1 & 2 & 3 & 4 \\
\hline
\end{tabular}

Keterangan simbol :

1 = Pewawancara/Respons Subjek

2 = Subjek $-1 /$ Subjek-2

$3=$ Kategori Efektivitas

4 = Platform Blended learning berbasis TKP-Kelase

Sebagai contoh, ketika suatu kumpulan data diberi kode "PFT101" maka ini bermakna data pewawancara subjek-1 pada kategori efektivitas 1 dengan Platform Blended learning berbasis TKP-Kelase dan merupakan pertanyaan nomor kesatu, yang diberi label“ $\mathrm{PF}$ ” atas pertanyaan peneliti pada wawancara subjek-1 pada kategori efektivitas 1 diberi label " T1 " pada pertanyaan nomor kesatu diberi label "01". Dengan demikian, bentuk label secara umum untuk jawaban subjek-1 adalah: "SFT101" maka hal ini berarti data terebut merupakan responden atau jawaban subjek-1 pada kategori efektivitas 1 dengan Platform Blended learning berbasis TKP-Kelase dan merupakan jawaban nomor kesatu. Sedangkan untuk pengodean data penelitian sebagai berikut. Pada kategori efektivitas 1 yaitu Kriteria Pendidikan (Educational Criteria) dilambangkan dengan huruf EC. Pada kategori efektivitas 2 yaitu Tampilan Program (Cosmetic) dilambangkan dengan huruf C. Pada kategori efektivitas 3 yaitu Kualitas Teknis (Technique Quality) dilambangkan dengan huruf TQ. Adapun kategori efektivitas Platform Blended learning berbasis TKP-Kelase dapat dilihat pada Tabel 1.
Tabel 1. Kategori Efektivitas Platform Blended Learning Berbasis TKP-Kelase

\begin{tabular}{|c|c|c|}
\hline $\begin{array}{c}\text { Kategori } \\
\text { Efektivitas }\end{array}$ & $\begin{array}{c}\text { Indikator efektivitas Platform } \\
\text { Blended learning berbasis } \\
\text { TKP-Kelase }\end{array}$ & Kode \\
\hline \multirow[t]{5}{*}{$\begin{array}{l}\text { Kriteria } \\
\text { Pendidikan } \\
\text { (Educational } \\
\text { Criteria) }\end{array}$} & $\begin{array}{l}\text { Topik-topik materi untuk setiap } \\
\text { jenjang pendidikan SMA/SMK } \\
\text { yang dimasukkan dalam } \\
\text { blended learning sudah sesuai } \\
\text { dengan kurikulum } 2013 \text {. }\end{array}$ & $\mathrm{EC} 1$ \\
\hline & $\begin{array}{l}\text { Materi pembelajaran } \\
\text { Matematika sudah tersusun } \\
\text { dari tingkat kesulitan terendah } \\
\text { sampai dengan tertinggi. }\end{array}$ & $\mathrm{EC} 2$ \\
\hline & $\begin{array}{l}\text { Konsep Manacika sudah } \\
\text { mampu meginternalisasi dalam } \\
\text { proses pembelajaran melalui } \\
\text { fitur-fitur yang disediakan } \\
\text { dalam blended learning yang } \\
\text { dibuat dengan platform kelase. }\end{array}$ & EC3 \\
\hline & $\begin{array}{l}\text { Konsep Wacika sudah mampu } \\
\text { menginternalisasi dalam proses } \\
\text { pembelajaran melalui fitur-fitur } \\
\text { yang disediakan dalam blended } \\
\text { learning yang dibuat dengan } \\
\text { platform kelase. }\end{array}$ & $\mathrm{EC} 4$ \\
\hline & $\begin{array}{l}\text { Konsep Kayika sudah mampu } \\
\text { menginternalisasi dalam proses } \\
\text { pembelajaran melalui fitur-fitur } \\
\text { yang disediakan dalam blended } \\
\text { learning yang dibuat dengan } \\
\text { platform kelase }\end{array}$ & EC5 \\
\hline \multirow{5}{*}{$\begin{array}{l}\text { Tampilan } \\
\text { Program } \\
\text { (Cosmetic) }\end{array}$} & $\begin{array}{l}\text { Tampilan blended learning } \\
\text { menarik. }\end{array}$ & $\mathrm{C} 1$ \\
\hline & $\begin{array}{l}\text { Blended learning mudah } \\
\text { diakses. }\end{array}$ & $\mathrm{C} 2$ \\
\hline & $\begin{array}{l}\text { Penyimpanan data pada } \\
\text { blended learning stabil. }\end{array}$ & C3 \\
\hline & Keamanan data terjaga. & $\mathrm{C} 4$ \\
\hline & $\begin{array}{l}\text { Dapat digunakan oleh multi } \\
\text { user dalam waktu bersamaan }\end{array}$ & $\mathrm{C} 5$ \\
\hline \multirow[t]{3}{*}{$\begin{array}{l}\text { Kualitas } \\
\text { Teknis } \\
\text { (Technique } \\
\text { Quality) }\end{array}$} & $\begin{array}{l}\text { Fitur-fitur blended learning } \\
\text { yang dibuat menggunakan } \\
\text { platform Kelase mudah } \\
\text { dioperasikan. }\end{array}$ & TQ1 \\
\hline & $\begin{array}{l}\text { Blended learning } \\
\text { menyediakan fasilitas yang } \\
\text { memudahkan untuk } \\
\text { mengunggah tugas. } \\
\end{array}$ & TQ2 \\
\hline & $\begin{array}{l}\text { Blended learning menyediakan } \\
\text { fasilitas forum diskusi antara } \\
\text { siswa dengan guru, siswa } \\
\text { dengan siswa }\end{array}$ & TQ3 \\
\hline
\end{tabular}

Berikut adalah bentuk gambar Platform Blended learning berbasis TKP-Kelase dan paparan wawancara subjek-1 dan subjek-2 pada kategori efektivitas kriteria pendidikan yang tercantum pada Gambar 1 dan Tabel 2. 


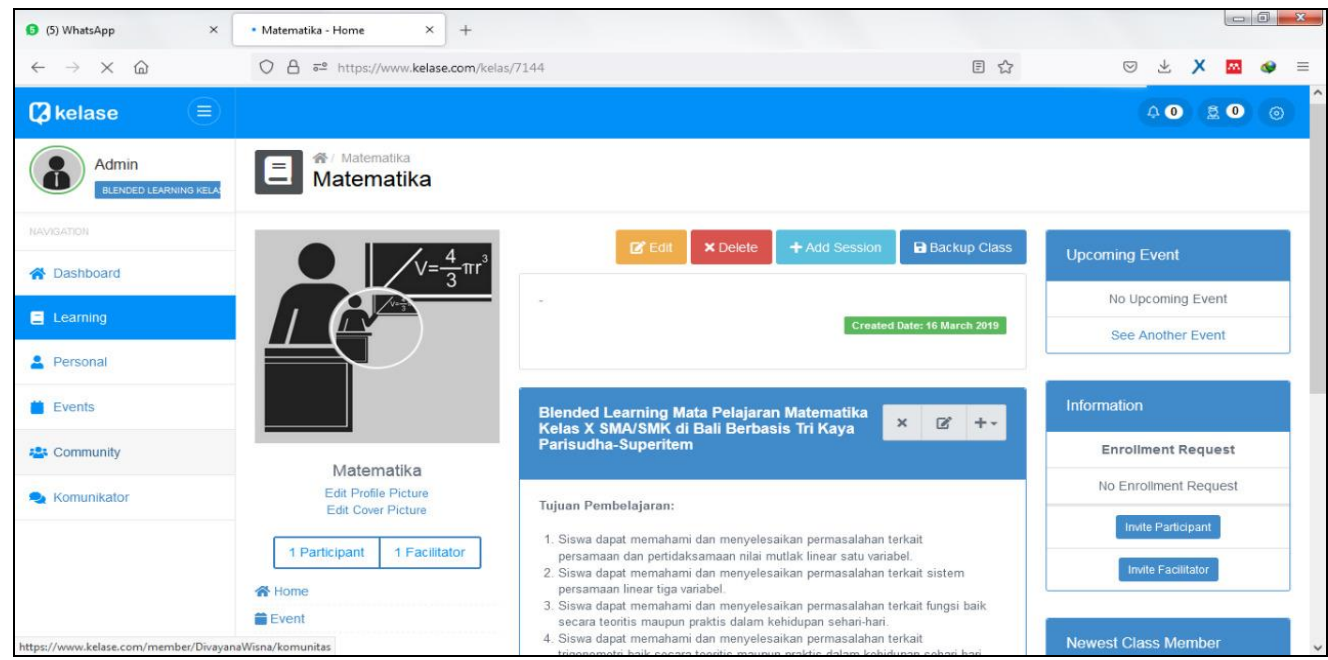

Gambar 1. Platform Blended Learning Berbasis TKP-Kelase Pada Bagian Kriteria Pendidikan

Tabel 2. Paparan Wawancara Subjek-1 dan Subjek-2 Pada Kategori Efektivitas Kriteria Pendidikan

\begin{tabular}{|c|c|c|c|}
\hline Label & Paparan Data & Label & Paparan Data \\
\hline PFT101 & $\begin{array}{l}\text { Coba ceritakan apa yang anda pahami dari } \\
\text { Platform Blended learning berbasis TKP- } \\
\text { Kelase tersebut? }\end{array}$ & PMT101 & $\begin{array}{l}\text { Coba ceritakan apa yang kamu pahami dari Platform } \\
\text { Blended learning berbasis TKP-Kelase tersebut? }\end{array}$ \\
\hline SFT101 & $\begin{array}{l}\text { Yang saya pahami dari Platform ini bahwa } \\
\text { Platform ini berisi materi pembelajaran } \\
\text { Matematika yang mirip dengan materi } \\
\text { pembelajaran dari buku paket yang didapat } \\
\text { dari sekolah (buku siswa kurikulum 2013). }\end{array}$ & SMT101 & $\begin{array}{c}\text { Materi pembelajaran yang terdapat dalam platform } \\
\text { ini adalah sama dengan isi buku siswa yang saya } \\
\text { dapat dari sekolah. }\end{array}$ \\
\hline PFT102 & Masih ada lagi yang ingin anda ceritakan? & PMT102 & Masih ada lagi yang ingin anda ceritakan? \\
\hline SFT102 & $\begin{array}{l}\text { Ya, awal-awalnya materi yang saya pelajari } \\
\text { dari platform ini terasa mudah tetapi makin } \\
\text { ke sini, malah makin sulit. }\end{array}$ & SMT102 & $\begin{array}{l}\text { Iya, saya dapat belajar Matematika dari yang paling } \\
\text { mudah hingga yang paling sulit di platform ini. }\end{array}$ \\
\hline PFT103 & $\begin{array}{l}\text { Menurut anda apakah melalui platform ini } \\
\text { anda mampu memfokuskan diri pada konsep } \\
\text { Manacika saat mengikuti pembelajaran? }\end{array}$ & PMT103 & $\begin{array}{l}\text { Menurut anda apakah melalui platform ini anda } \\
\text { mampu memfokuskan diri pada konsep Manacika } \\
\text { saat mengikuti pembelajaran? }\end{array}$ \\
\hline SFT103 & $\mathrm{Ya}$ & SMT103 & Iya \\
\hline PFT104 & Mengapa? & PMT104 & Mengapa? \\
\hline SFT104 & $\begin{array}{l}\text { Keran melalui materi pembelajaran yang } \\
\text { disediakan dalam platform ini mempengaruhi } \\
\text { saya untuk berpikir positif. }\end{array}$ & SMT104 & $\begin{array}{l}\text { Karena pelajaran yang ada pada platform ini } \\
\text { menggiring pemikiran saya ke arah yang lebih baik. }\end{array}$ \\
\hline PFT105 & $\begin{array}{l}\text { Menurut anda apakah melalui platform ini } \\
\text { anda mampu memfokuskan diri pada konsep } \\
\text { Wacika saat mengikuti pembelajaran? } \\
\text { Mengapa? }\end{array}$ & PMT105 & $\begin{array}{l}\text { Menurut anda apakah melalui platform ini anda } \\
\text { mampu memfokuskan diri pada konsep Wacika saat } \\
\text { mengikuti pembelajaran? Mengapa? }\end{array}$ \\
\hline SFT105 & $\begin{array}{l}\text { Ya, karena sudah tertera pada aturan tata } \\
\text { tertib diskusi harus menggunakan kalimat } \\
\text { yang baik dan sopan. }\end{array}$ & SMT105 & $\begin{array}{l}\text { Iya, karena sudah ada tata tertibnya dan sudah } \\
\text { ditegaskan juga oleh guru untuk selalu menjaga } \\
\text { kesantunan dalam berucap. }\end{array}$ \\
\hline PFT106 & $\begin{array}{c}\text { Menurut anda apakah melalui platform ini } \\
\text { anda mampu memfokuskan diri pada konsep } \\
\text { Kayika saat mengikuti pembelajaran? } \\
\text { Mengapa? }\end{array}$ & PMT106 & $\begin{array}{l}\text { Menurut anda apakah melalui platform ini anda } \\
\text { mampu memfokuskan diri pada konsep Kayika saat } \\
\text { mengikuti pembelajaran? Mengapa? }\end{array}$ \\
\hline SFT106 & $\begin{array}{l}\text { Ya, karena materi pelajaran yang ada pada } \\
\text { platform ini mengajarkan saya untuk berbuat } \\
\text { baik selain mempelajari materi Matematika. }\end{array}$ & SMT106 & $\begin{array}{l}\text { Iya, karena pembelajaran pada platform ini } \\
\text { mengarahkan saya untuk selalu berbuat baik di } \\
\text { samping mempelajari matematika. }\end{array}$ \\
\hline PFT107 & $\begin{array}{c}\text { Menurut anda apakah ada kontribusi dari } \\
\text { konsep Manacika, Wacika dan Kayika pada } \\
\text { pembelajaran Matematika menggunakan } \\
\text { platform ini? Mengapa? }\end{array}$ & PMT107 & $\begin{array}{l}\text { Menurut anda apakah ada kontribusi dari konsep } \\
\text { Manacika, Wacika dan Kayika pada pembelajaran } \\
\text { Matematika menggunakan platform ini? Mengapa? }\end{array}$ \\
\hline SFT107 & $\begin{array}{l}\text { Ada, karena ada penilaian untuk Manacika, } \\
\text { Wacika dan Kayika pada platform ini. }\end{array}$ & SMT107 & $\begin{array}{l}\text { Tentu saja ada, karena jika menggunakan platform } \\
\text { ini, penilaian ketiga konsep ini akan mempengaruhi } \\
\text { nilai matematika saya }\end{array}$ \\
\hline
\end{tabular}


Berdasarkan hasil analisis data paparan wawancara di atas diperoleh bahwa efektifitas Platform Blended learning berbasis TKP-Kelase telah memenuhi standarisasi pada kategori kriteria pendidikan. Hal tersebut sesuai dengan hasil wawancara pada subjek-1 dan subjek-2 yang memberi penjelasan bahwa Topiktopik materi untuk setiap jenjang pendidikan SMA/SMK yang dimasukkan dalam blended learning sudah sesuai dengan kurikulum 2013 (EC1). Sejalan dengan hasil mengatakan bahwa suatu platform pembelajaran yang baik adalah platform pembelajaran yang mencantumkan materi pembelajaran sesuai dengan kurikulum yang berlaku pada satuan pendidikan dalam suatu negara penelitian (Lee et al, 2019). Hasil wawancara subjek-1 dan subjek-2 juga memberi penjelasan bahwa materi pembelajaran Matematika pada Platform Blended learning berbasis TKP-Kelase sudah tersusun dari tingkat kesulitan terendah sampai dengan tertinggi (EC2). Hal ini sesuai dengan bahwa penyusunan materi pembelajaran Matematika haruslah mengutamakan sistematika untuk menghindari kebingungan siswa saat mempelajarinya (Simsek \& Yazici, 2021). Selain itu berdasarkan hasil wawancara subjek-1 dan subjek-2 juga memberi penjelasan bahwa konsep Manacika, Wacika dan Kayika sudah mampu menginternalisasi dalam proses pembelajaran melalui fitur-fitur yang disediakan dalam blended learning yang dibuat dengan platform kelase (EC3, EC4, dan EC5). Hal ini sejalan dengan hasil penelitian Huang (2021) yang mengatakan bahwa dalam pembelajaran blended learning sangatlah penting untuk melaksanakan penilaian di tiga ranah yang dikemukakan oleh Bloom.

Bentuk gambar Platform Blended learning berbasis TKP-Kelase pada kategori efektivitas tampilan program dapat dilihat pada Gambar 2, sedangkan paparan hasil wawancara subjek-1 dan subjek-2 pada bagian ini tercantum pada Tabel 3 .

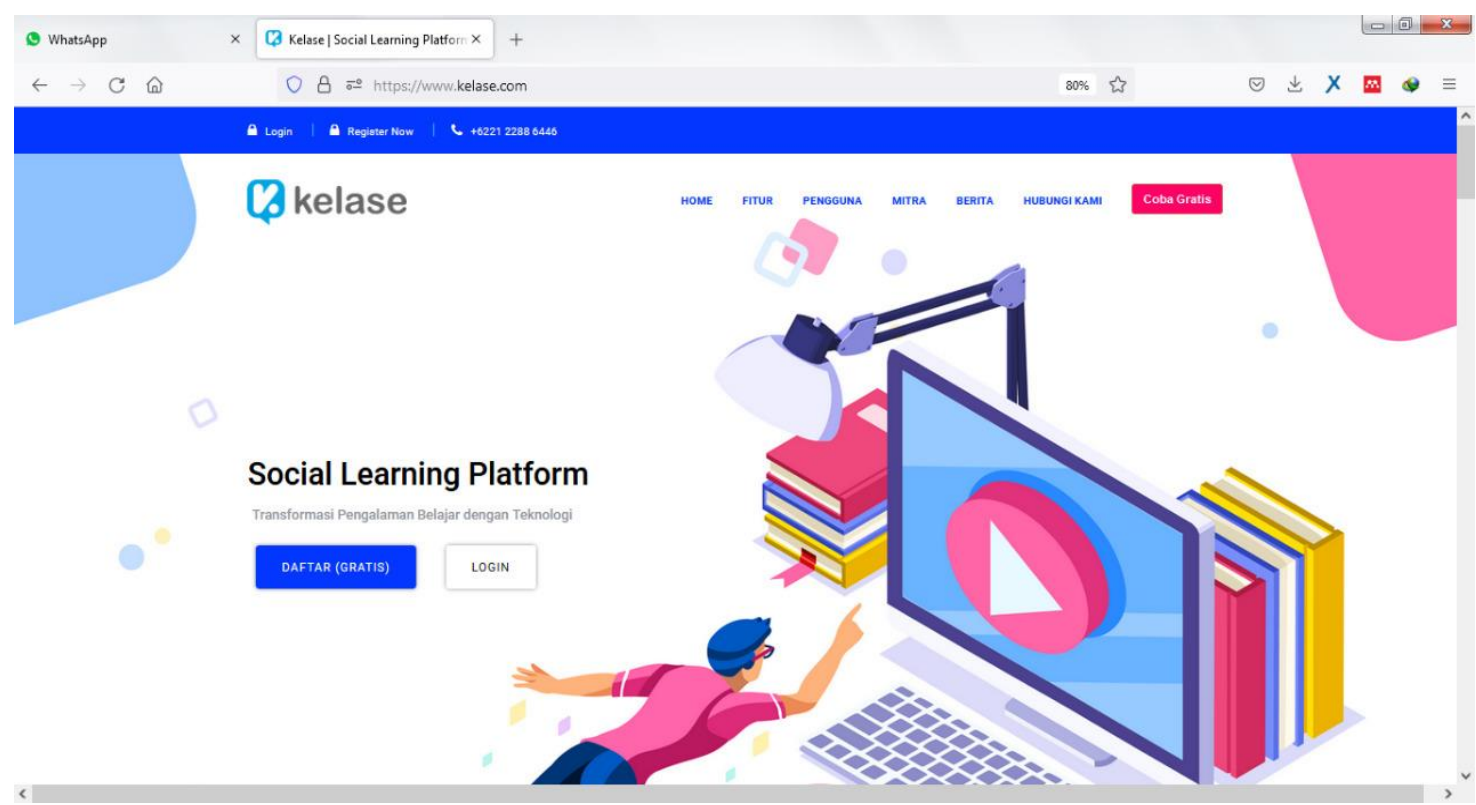

Gambar 2. Platform Blended learning berbasis TKP-Kelase pada bagian Kriteria Tampilan Program 
Tabel 3. Paparan Wawancara Subjek-1 dan Subjek-2 Pada Kategori Efektivitas Tampilan Program

\begin{tabular}{|c|c|c|c|}
\hline Label & Paparan Data & Label & Paparan Data \\
\hline $\begin{array}{l}\text { PFT } \\
201\end{array}$ & $\begin{array}{l}\text { Berdasarkan informasi dan pemahaman anda, coba } \\
\text { ceritakan ke menarikkan dari platform tersebut? }\end{array}$ & PMT 201 & $\begin{array}{l}\text { Berdasarkan informasi dan pemahaman anda, coba } \\
\text { ceritakan ke menarikkan dari platform tersebut? }\end{array}$ \\
\hline $\begin{array}{l}\text { SFT } \\
201\end{array}$ & $\begin{array}{c}\text { Menurut saya platform ini menarik, karena pewarnaannya } \\
\text { saya suka, suara dan animasi nya pas, kemudian } \\
\text { bahasanya juga mudah dimengerti. }\end{array}$ & SMT 201 & $\begin{array}{c}\text { Menurut saya platform ini menarik, karena padu- } \\
\text { padan warnanya tidak menyakiti mata, animasi nya } \\
\text { juga menarik, dan dari segi bahasanya sangat } \\
\text { mudah untuk saya cerna. }\end{array}$ \\
\hline $\begin{array}{l}\text { PFT } \\
202\end{array}$ & Bagaimana dengan proses aksesnya platform ini? & PMT 202 & Bagaimana dengan proses aksesnya platform ini? \\
\hline $\begin{array}{l}\text { SFT } \\
202\end{array}$ & Proses aksesnya sangat mudah. & SMT 202 & $\begin{array}{c}\text { Mengakses platform ini mudah, tidak se-rumit } \\
\text { platform yang lain. }\end{array}$ \\
\hline $\begin{array}{l}\text { PFT } \\
203\end{array}$ & $\begin{array}{c}\text { Bagaimana dengan kestabilan penyimpanan data pada } \\
\text { platform ini? }\end{array}$ & PMT 203 & $\begin{array}{c}\text { Bagaimana dengan kestabilan penyimpanan data } \\
\text { pada platform ini? }\end{array}$ \\
\hline $\begin{array}{l}\text { SFT } \\
203\end{array}$ & Penyimpanan datanya terbatas, dan tidak berubah-ubah. & SMT 203 & $\begin{array}{c}\text { Penyimpanan data nya tetap, selalu sama, itu berarti } \\
\text { akan stabil. }\end{array}$ \\
\hline $\begin{array}{l}\text { PFT } \\
204\end{array}$ & $\begin{array}{l}\text { Apakah menurut anda, keamanan data pada platform ini } \\
\text { terjaga? }\end{array}$ & PMT 204 & $\begin{array}{l}\text { Apakah menurut anda, keamanan data pada } \\
\text { platform ini terjaga? }\end{array}$ \\
\hline $\begin{array}{l}\text { SFT } \\
204\end{array}$ & Ya, karena sudah ada password nya & SMT 204 & $\begin{array}{c}\text { Iya, karena masing-masing dari kami mendapatkan } \\
\text { password dan user name untuk mengakses data } \\
\text { pribadi kami. }\end{array}$ \\
\hline $\begin{array}{l}\text { PFT } \\
205\end{array}$ & $\begin{array}{c}\text { Apakah banyak orang bisa menggunakan platform ini } \\
\text { dalam waktu yang bersamaan? }\end{array}$ & PMT 205 & $\begin{array}{l}\text { Apakah banyak orang bisa menggunakan platform } \\
\text { ini dalam waktu yang bersamaan? }\end{array}$ \\
\hline $\begin{array}{l}\text { SFT } \\
205\end{array}$ & Ya, bisa. & SMT 205 & $\begin{array}{l}\text { Bisa, saya pernah mencobanya dengan beberapa } \\
\text { teman saya. }\end{array}$ \\
\hline
\end{tabular}

Berdasarkan hasil analisis data paparan wawancara di atas diperoleh bahwa efektifitas Platform Blended learning berbasis TKP-Kelase telah memenuhi standarisasi pada kategori tampilan program. Hal tersebut sesuai dengan hasil wawancara pada subjek-1 dan subjek-2 yang memberi penjelasan bahwa tampilan platform Blended learning berbasis TKP-Kelase menarik (C1). Sejalan dengan hasil penelitian Khan et al. (2017), dinyatakan bahwa suatu platform pembelajaran dapat dikatakan menarik jika pewarnaan, penggunaan bahasa, design, suara, animasi dan grafis nya mudah untuk dipahami.

Hasil wawancara subjek-1 dan subjek-2 juga memberi penjelasan bahwa Platform Blended learning berbasis TKP-Kelase mudah untuk diakses dan penyimpanan datanya juga stabil (C2 dan C3). Suatu platform memenuhi standar untuk digunakan jika platform tersebut mudah untuk diakses dan penyimpanan datanya tidak berubah-ubah (Land \& Booth, 2020). Selain itu berdasarkan hasil wawancara subjek-1 dan subjek-2 juga memberi penjelasan bahwa keamanan data pada platform ini terjaga dan dapat digunakan oleh multi user dalam waktu bersamaan (C4 dan C5). Platform pembelajaran yang dibutuhkan suatu sekolah adalah platform yang multi user dan keamanan datanya terjaga (Hillman, Rensfeldt, \& Ivarsson, 2020).

Bentuk gambar Platform Blended learning berbasis TKP-Kelase pada kategori efektivitas kualitas teknis dapat dilihat pada Gambar 3 dan paparan hasil wawancara subjek-1 dan subjek-2 pada bagian ini tercantum pada Tabel 4.

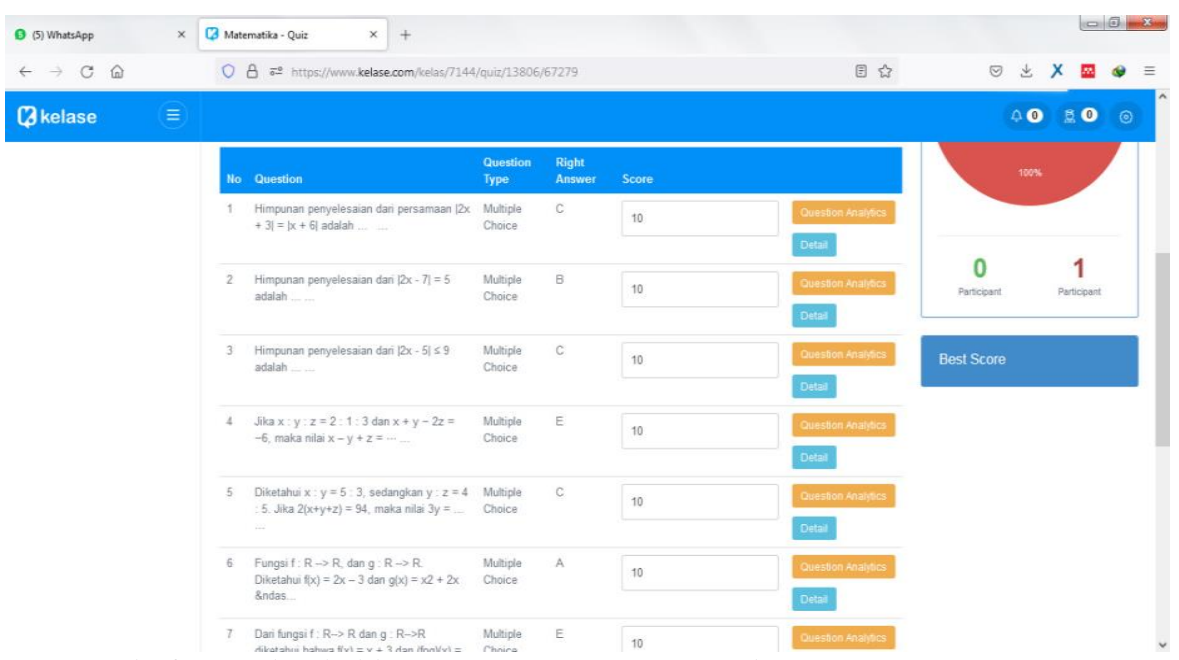

Gambar 3. Platform Blended learning berbasis TKP-Kelase pada bagian Kualitas Teknis 
Tabel 4. Paparan Wawancara Subjek-1 dan Subjek-2 Pada Kategori Efektivitas Kualitas Teknis

\begin{tabular}{|c|c|c|c|}
\hline Label & Paparan Data & Label & Paparan Data \\
\hline $\begin{array}{l}\text { PFT } \\
301\end{array}$ & $\begin{array}{c}\text { Coba anda } \\
\text { jelaskan, } \\
\text { bagaimana } \\
\text { menurut anda } \\
\text { pengoperasian } \\
\text { platform Blended } \\
\text { learning berbasis } \\
\text { TKP-Kelase ini? }\end{array}$ & $\begin{array}{c}\text { PMT3 } \\
01\end{array}$ & $\begin{array}{c}\text { Coba anda } \\
\text { jelaskan, } \\
\text { bagaimana } \\
\text { menurut anda } \\
\text { pengoperasian } \\
\text { platform Blended } \\
\text { learning berbasis } \\
\text { TKP-Kelase ini? }\end{array}$ \\
\hline $\begin{array}{l}\text { SFT } \\
301\end{array}$ & $\begin{array}{c}\text { Menurut saya, } \\
\text { pengoperasiannya } \\
\text { tidak susah. }\end{array}$ & $\begin{array}{c}\text { SMT3 } \\
01\end{array}$ & $\begin{array}{c}\text { Saat saya } \\
\text { menggunakan } \\
\text { platform ini, saya } \\
\text { tidak menemukan } \\
\text { kesulitan }\end{array}$ \\
\hline $\begin{array}{l}\text { PFT } \\
302\end{array}$ & $\begin{array}{c}\text { Bagaimana } \\
\text { penggunaan } \\
\text { platform ini } \\
\text { ketika anda harus } \\
\text { mengumpulkan } \\
\text { tugas? }\end{array}$ & $\begin{array}{c}\text { PMT3 } \\
02\end{array}$ & $\begin{array}{c}\text { Bagaimana } \\
\text { penggunaan } \\
\text { platform ini ketika } \\
\text { anda harus } \\
\text { mengumpulkan } \\
\text { tugas? }\end{array}$ \\
\hline $\begin{array}{l}\text { SFT } \\
302\end{array}$ & $\begin{array}{c}\text { Saat } \\
\text { mengumpulkan } \\
\text { tugas di platform } \\
\text { ini sudah tersedia } \\
\text { fasilitas untuk } \\
\text { mengunggah } \\
\text { tugas. }\end{array}$ & $\begin{array}{c}\text { SMT3 } \\
02\end{array}$ & $\begin{array}{c}\text { Platform ini } \\
\text { menyediakan } \\
\text { menu untuk } \\
\text { melakukan upload } \\
\text { tugas }\end{array}$ \\
\hline $\begin{array}{l}\text { PFT } \\
303\end{array}$ & $\begin{array}{c}\text { Bagaimana } \\
\text { penggunaan } \\
\text { platform ini saat } \\
\text { pembelajaran } \\
\text { harus melakukan } \\
\text { diskusi? }\end{array}$ & $\begin{array}{c}\text { PMT3 } \\
03\end{array}$ & $\begin{array}{c}\text { Bagaimana } \\
\text { penggunaan } \\
\text { platform ini saat } \\
\text { pembelajaran } \\
\text { harus melakukan } \\
\text { diskusi? }\end{array}$ \\
\hline $\begin{array}{l}\text { SFT } \\
303\end{array}$ & $\begin{array}{l}\text { Platform ini } \\
\text { sudah } \\
\text { menyediakan } \\
\text { forum diskusi } \\
\text { untuk kami } \\
\text { berdiskusi. } \\
\end{array}$ & $\begin{array}{c}\text { SMT3 } \\
03\end{array}$ & $\begin{array}{c}\text { Pada platform ini } \\
\text { tersedia forum } \\
\text { diskusi untuk kami } \\
\text { berdiskusi }\end{array}$ \\
\hline $\begin{array}{l}\text { PFT } \\
304\end{array}$ & $\begin{array}{l}\text { Ada lagi yang } \\
\text { ingin di-review } \\
\text { terkait platform } \\
\text { ini? }\end{array}$ & $\begin{array}{c}\text { PMT3 } \\
04\end{array}$ & $\begin{array}{c}\text { Ada lagi yang } \\
\text { ingin di-review } \\
\text { terkait platform } \\
\text { ini? }\end{array}$ \\
\hline $\begin{array}{l}\text { SFT } \\
304\end{array}$ & $\begin{array}{l}\text { Ya, pokoknya } \\
\text { platform ini } \\
\text { memudahkan } \\
\text { kami untuk } \\
\text { belajar. }\end{array}$ & $\begin{array}{c}\text { SMT3 } \\
04\end{array}$ & $\begin{array}{c}\text { Intinya } \\
\text { pembelajaran } \\
\text { Matematika kami } \\
\text { lebih terbantu } \\
\text { dengan adanya } \\
\text { platform ini. }\end{array}$ \\
\hline
\end{tabular}

Berdasarkan hasil analisis data paparan wawancara di atas diperoleh bahwa efektifitas Platform Blended learning berbasis TKP-Kelase telah memenuhi standarisasi pada kategori kualitas teknis. Hal tersebut sesuai dengan hasil wawancara pada subjek-1 dan subjek-2 yang memberi penjelasan bahwa fitur-fitur blended learning yang dibuat menggunakan platform Kelase mudah dioperasikan (TQ1). Suatu platform pembelajaran yang baik adalah platform pembelajaran yang mudah untuk dioperasikan oleh khalayak umum (Wang et al, 2020). Hasil wawancara subjek-1 dan subjek-2 juga memberi penjelasan bahwa Platform Blended learning berbasis TKP-Kelase menyediakan fasilitas yang memudahkan untuk mengunggah tugas (TQ2). Platform pembelajaran haruslah menyediakan fasilitas untuk siswanya melakukan unggahan tugas (Lee \& Yeong, 2020). Selain itu berdasarkan hasil wawancara subjek-1 dan subjek-2 juga memberi penjelasan bahwa Platform Blended learning berbasis TKP-Kelase menyediakan fasilitas forum diskusi antara siswa dengan guru, dan siswa dengan siswa (TQ3). Dalam pembelajaran blended learning sangatlah penting untuk melaksanakan diskusi (Huang, 2021).

\section{KESIMPULAN}

Hasil wawancara terhadap subjek-1 dan subjek-2 memiliki kesamaan dalam profil efektifitas platform blended learning berbasis TKP-Kelase pada pembelajaran Matematika. Profil efektifitas platform blended learning berbasis TKP-Kelase pada pembelajaran Matematika memenuhi standarisasi pada tiga kategori, diantaranya: kriteria pendidikan (educational criteria), tampilan program (cosmetic), dan kualitas teknis (technique quality). Beberapa kode indikator yang termasuk dalam kriteria pendidikan, diantaranya: EC1, EC2, EC3, EC4, dan EC5. Beberapa kode indikator yang termasuk dalam kriteria tampilan program, diantaranya: $\mathrm{C} 1, \mathrm{C} 2, \mathrm{C} 3, \mathrm{C} 4$, dan C5. Beberapa kode indikator yang termasuk dalam kriteria kualitas teknis, diantaranya: TQ1, TQ2, dan TQ3.

\section{SARAN}

Profil platform blended learning berbasis TKPKelase pada pembelajaran Matematika ini baru dianalisis berdasarkan hasil wawancara terhadap siswa yang berkemampuan sedang. Ke depan agar dilakukan analisis terhadap guru dan pakar terkait efektifitas platform blended learning berbasis TKP-Kelase pada pembelajaran Matematika.

\section{DAFTAR PUSTAKA}

Ariawan, I.P.W., Divayana, D.G.H., \& Suyasa, P.W.A. (2020). Initial Design of Blended Learning for Mathematics Subject Using the Kelase Platform by Adopting Content of Tri Kaya Parisudha. Journal of Physics: Conf. Series, 1470, 1-6.

Arifin, Z., Febriani, S.R., \& Anasruddin. (2021). Using Bloom's Taxonomy in Arabic Learning Media to Elevate Students' Writing in COVID-19 Situation. Jurnal Ilmiah Program Studi Pendidikan Bahasa Arab IAIN Palangka Raya, 9(1), 1-12.

Babakr, Z.H., Mohamedamin, P., \& Kakamad, K. (2019). Piaget's Cognitive Developmental Theory: Critical Review. Education Quarterly Reviews, 2(3), 517-524.

Busto, S., Dumbser, M., \& Gaburro, E. (2021). A Simple but Efficient Concept of Blended Teaching of 
Mathematics for Engineering Students During the COVID-19 Pandemic. Education Sciences 11(2), $1-24$.

Dolighan, T., \& Owen, M. (2021). Teacher Efficacy for Online Teaching during the COVID-19 Pandemic. Brock Education: A Journal of Educational Research and Practice, 30(1), 95-116.

EL-Ariss, B., Zaneldin, E., \& Ahmed, W. (2021). Using Videos in Blended E-Learning for a Structural Steel Design Course. Education Sciences, 11(290),1-18.

Green, R.A., \& Whitburn, L.Y. (2016). Impact of Introduction of Blended Learning in Gross Anatomy on Student Outcomes. Anatomical Sciences Education, 9(5):422-430.

Helsa, Y., \& Kenedi, A.K. (2019). Edmodo-Based Blended Learning Media in Learning Mathematics. Journal of Teaching and Learning in Elementary Education, 2(2), 107-117.

Hillman, T., Rensfeldt, A.B., \& Ivarsson, J. (2020). Brave New Platforms: A Possible Platform Future for Highly Decentralised Schooling. Learning, Media and Technology, 45(1), 7-16.

Huang, C.H. (2021). Using PLS-SEM Model to Explore the Influencing Factors of Learning Satisfaction in Blended Learning. Education Sciences, 11(5), 117.

Khan, S., Jaffery, M.H., Hanif, A., \& Asif, M.R. (2017). "Teaching Tool for a Control Systems Laboratory Using a Quadrotor as a Plant in MATLAB. IEEE Transactions on Education, 60(4), 249-256.

Land, S.C., \& Booth, D. (2020). Systematic Review and Meta-Analysis as a Structured Platform for Teaching Principles of Experimentation. Advances in Physiology Education, 44(3), 276-285.

Lee, T., An, J., Sohn, H., \& Yoo, I.T. (2019). An Experiment of Community-Based Learning Effects on Civic Participation. Journal of Political Science Education, 15(4), 443-458.

Lee, Z.W., \& Yeong, F.M. (2020). Online Conferencing
Platform Provides Opportunity for Reciprocal Teaching. Biochemistry and Molecular Biology Education, 48(5), 471-472.

Muhtia, A, Suparno, \& Sumardi. (2018). Blended Learning Using Schoology as an Online Learning Platform. ELLiC Proceedings, 2, 171-175.

Simsek, M., \& Yazici, N. (2021). Examining the Digital Learning Material Preparation Competencies of Pre-Service Mathematics Teachers. Participatory Educational Research, 8(3), 323-343.

Sugiharni, G.A.D. (2018). Pengujian Validitas Konten Media Pembelajaran Interaktif Berorientasi Model Creative Problem Solving. Jurnal Penelitian dan Pengembangan Pendidikan, 2(2), 88-95.

Sulisworo, D., Agustin, S.P., \& Sudarmiyati, E. (2016). Cooperative-Blended Learning Using Moodle as an Open Source Learning Platform. International Journal of Technology Enhanced Learning, 8(2), 187-198.

Wang, L., Zhen, Z., Wo, T., Jiang, B., Sun, H., \& Long, X. (2020). A Scalable Operating System Experiment Platform Supporting Learning Behavior Analysis. IEEE Transactions on Education, 63(3), 232-239.

Wijanayu, A., Hardyanto, W., \& Isnaeni, W. (2018). Blended Learning Method Based on Quipper School to Improve Concepts Understanding and Independence Learning. Journal of Primary Education, 7(1), 88 -95.

\section{UCAPAN TERIMA KASIH}

Penulis mengucapkan terima kasih kepada Direktorat Jenderal Riset dan Pengembangan, Badan Riset dan Inovasi Nasional Republik Indonesia yang telah memberikan kesempatan dan pendanaan dalam

melaksanakan penelitian di beberapa SMA dan SMK di Bali. Pendanaan dalam penelitian ini diberikan berdasarkan SK Kontrak Penelitian No. 178/UN48.16/LT/2021. 